\title{
Education's Impact On Children's Knowledge Levels About COVID-19 And How To Prevent It In The Surabaya City
}

\author{
Emyrazel Fahdizhar ${ }^{1}$, Muhammad Raihan Habibi ${ }^{1}$, Muazza Mubaroka ${ }^{1}$, \\ Widati Fatmaningrum ${ }^{2}$ \\ ${ }^{2}$ Email : widati-f@fk.unair.ac.id \\ ${ }^{1}$ Medical Study Program, Faculty of Medicine, University of Airlangga, Surabaya 60132, Indonesia \\ ${ }^{2}$ Department of Public Health, Faculty of Medicine, University of Airlangga, Surabaya 60132, Indonesia
}

\begin{abstract}
Background: Coronavirus Disease 2019 (COVID-19) is an infectious disease caused by a new type of coronavirus that has never been previously identified in humans called Severe Acute Respiratory Syndrome Coronavirus 2 (SARS-CoV-2). The CDC (2021) gave a Level 4 warning to Indonesia, which means that the transmission of COVID-19 in this country is very high. The health protocols followed by clean and healthy living behavior can be applied to break the chain of transmission of COVID-19. Therefore, programs based on health education and promotion to increase public awareness of the importance of complying with health protocols are urgently needed. This study aimed to know the profile of education's impact on children's knowledge about COVID-19 to implement COVID-19 transmission prevention behavior in everyday life. Methods: We provide an educational lecture about COVID-19 prevention for elementary and high school children. We observed gender, educational history, pretest scores, and posttest scores. The pretest and posttest data were then analyzed using the IBM SPSS Statistics 23 application with the Paired Samples T-Test type of test to determine whether there were differences in the level of knowledge before and after educational activities. The data is presented in the form of a statistical table. Result: There were 18 samples of children as participants included in this study. Most of the children are female, most of them attend secondary school and high school levels. There was an increase in scores from pretest to posttest after participants were given education lecture about COVID-19 and how to prevent it. Conclusion: Providing education using PowerPoint, educational videos, and direct handwashing practice can increase knowledge about COVID-19 and its prevention. Continuous education is needed to increase knowledge \& improve public perception and behavior towards COVID-19.
\end{abstract}

Keywords: COVID-19; Education; Well-being

\section{Introduction}

Coronavirus Disease 2019 (COVID-19) is an infectious disease caused by a new type of coronavirus that has never been previously identified in humans called Severe Acute Respiratory Syndrome Coronavirus 2 (SARS-CoV-2). This new type of coronavirus case was first detected as a respiratory disease in Wuhan, Hubei province, China, at the end of 2019. On March 11, 2020, WHO declared COVID-19 pandemic [1]. The increase in the number of COVID-19 cases took place quite quickly and had spread to various countries in a short time. Since March 2, 2020, Indonesia has reported its first case, and until July 21, 2021, positive confirmed cases in Indonesia have almost reached 3 million cases with more than 76,000 deaths [2]. 
The CDC (2021) health agency gave a Level 4 warning to Indonesia, which means that the transmission of COVID-19 in this country is very high [3]. Recommendations for wearing masks, washing hands, maintaining distance, limiting mobility, avoiding crowds, and avoiding eating together contained in the health protocols followed by clean and healthy living behavior can be applied to break the chain of transmission of COVID- 19 . Therefore, programs based on health education and promotion to increase public awareness of the importance of complying with health protocols and general well-being are urgently needed. Knowledge is also the most binding domain in behavior formation [4]. Public knowledge about COVID-19 is needed as the basis of society in showing COVID-19 prevention behavior. Therefore, we are holding community service activities, one of which is educational activities regarding COVID-19 and how to prevent it at the Al-Jihad Islamic Boarding School Surabaya, which was held on Sunday, July 18, 2021, 08.00 AM - 11.15 AM in West Indonesian Time. This study aimed to know the profile of education's impact on children's knowledge about COVID-19 to implement COVID-19 transmission prevention behavior in daily life.

\section{Method}

This activity is a community service activity to educate children at the elementary, secondary school, and high school levels about COVID-19 at the Al-Jihad Islamic Boarding School in Surabaya. The number of participants who took part in this activity was 18 children. The activity began by giving pretest questionnaires to the participants, then continued with counseling in the form of educational activities regarding the introduction of COVID-19 and health protocols behavior using PowerPoint slides, educational videos, and direct hand washing practices. After the educational activities were completed, participants were given a posttest. The activity was evaluated by analyzing the participants' pretest and posttest scores and other variables such as gender and educational history. The evaluation was carried out to measure the children's knowledge level before and after the educational activities. The pretest and posttest data were then analyzed using the IBM SPSS Statistics 23 application with the Paired Samples T-Test type of test to determine whether there were differences in the level of knowledge before and after educational activities. The data is presented in the form of a statistical table.

\section{Result}

Table 1. Demographic Characteristics by Gender and Educational History

\begin{tabular}{lcc}
\hline Characteristics & Frequency (N) & Percentage (\%) \\
\hline Gender & 7 & 38,88 \\
Male & 11 & 61,11 \\
Female & & \\
Educational History & 2 & 11,11 \\
Elementary School & 8 & 44,44 \\
Secondary School & 8 & 44,44 \\
High School & 8 & \\
\hline
\end{tabular}

Eighteen children participated in the COVID-19 education and prevention at the Al-Jihad Islamic Boarding School in Surabaya. The demographic characteristics of the participants are summarized in table 1. Most of the participants are currently studying in secondary school and high school, with eight children (44.44\%) and more female participants $(61.11 \%)$ than male participants $(38.88 \%)$. 
Tabel 2. Demographic Characteristics by Gender and Educational History

\begin{tabular}{|c|c|c|c|c|}
\hline Characteristics & Pretest (Min.) & Post-test (Max.) & Pretest (Min.) & Post-test (Max.) \\
\hline \multicolumn{5}{|l|}{ Gender } \\
\hline Male & 20 & 90 & 30 & 90 \\
\hline Female & 50 & 90 & 50 & 100 \\
\hline \multicolumn{5}{|l|}{ Educational History } \\
\hline Elementary School & 20 & 70 & 30 & 60 \\
\hline Secondary School & 30 & 100 & 60 & 100 \\
\hline High School & 50 & 90 & 60 & 100 \\
\hline $\begin{array}{l}\text { Total } \\
\text { Mean }\end{array}$ & \multicolumn{2}{|c|}{$\begin{array}{l}71.11 \\
21.74\end{array}$} & \multicolumn{2}{|c|}{$\begin{array}{l}79.44 \\
19.29\end{array}$} \\
\hline
\end{tabular}

Table 2 shows the minimum and maximum scores on the pretest and posttest by gender and educational history. The minimum pretest score is 20 and lower than the posttest minimum score, which is 30 . The maximum score for both pretest and posttest is the same, which is 100 .

Tabel 3. Statistical data on the increase in scores and the results of the Paired Samples T-Test based on the Pretest and Posttest scores.

\begin{tabular}{|c|c|c|c|}
\hline Score & Mean & SD & $p$ \\
\hline Pretest & \multirow[b]{2}{*}{8.33} & \multirow[b]{2}{*}{15.81} & \multirow[b]{2}{*}{0,039} \\
\hline Post-test & & & \\
\hline
\end{tabular}

In table 3, the mean (mean) pretest score is $71.11+21.74$. Meanwhile, the average posttest score showed an increase to $79.44+19.24$. The average increase in value is $8.33+15.81$. Based on the Paired Samples T-Test results, it was found that the significance $(p)=0.039<0.05$. So, it can be concluded that there was a significant difference between the knowledge level about COVID-19 and its prevention in pretest and posttest data after being given education about COVID-19 and how to prevent it.

\section{Discussion}

The widespread use of gadgets and the internet in the era of the COVID-19 pandemic has made access to information easy to obtain, whether the information is correct. Adequate knowledge and good behavior are also needed to filter the current information and prevent the transmission of COVID-19. According to Notoatmodjo, knowledge is a cognitive domain that significantly influences one's actions. Acceptance of new behavior will be better based on knowledge, while the behavior will not last long without knowledge [5] [6]. Someone who knows certain information can determine and make decisions about the solution [7]. In this case, when a person has information about COVID-19, they will determine how they should react to the infectious disease.

In this community service activity, the subject was given a questionnaire in the form of a pretest before educating about COVID-19 and its prevention. Then a posttest questionnaire was also given after the educational activities were completed. Based on the Paired Samples T-Test result in Table 3, there was a significant difference between the level of knowledge in the pretest and posttest after providing education about COVID-19 and its prevention. It shows that using PowerPoint media, educational videos, and direct practice of proper handwashing could increase children's knowledge about COVID-19 and its prevention through the provision of education. The study results are supported by Purabayanti et al. (2021), which shows a difference between the pretest and posttest results, which means that there is an increase in the knowledge of 
orphanage children about preventing the transmission of COVID-19 after being given education [8]. A study by Rahmadeni et al. (2019) also supports the evaluation results of this activity, that counseling activities in the form of Clean and Healthy Life Behavior education could increase children's knowledge [9].

In line with the evaluation results of this activity, a study by Zukmadini et al. (2020) stated that education about Clean and Healthy Life Behavior in COVID-19 Prevention could increase children's knowledge [10]. It is evidenced by the increase in the percentage of participants' knowledge before the activity, which was $74.48 \%$, then increased to $86.48 \%$ after the educational activity. The results of the evaluation of this activity are also in line with a study by Erlin et al. (2020), which stated that there was an increase in students' knowledge about preventing COVID-19, which was initially $100 \%$ low to $75 \%$ high after providing education regarding COVID-19 prevention [11]. It proves the importance of continuing education to increase public knowledge about COVID-19. Good knowledge can be supported by accepting information about COVID-19 circulating in the community [12].

Education is needed to improve people's perceptions that are still not quite right. According to Olum R, Chekwueh et al. (2020), continuing professional education is needed to increase knowledge, practice prevention, treatment, and change negative behavior [13]. A study in China by Zhong et al. (2020) found a relationship between knowledge and attitudes towards COVID-19 [14]. A better level of knowledge is a protective factor against insecurity in the face of COVID-19. A study by Wardhani et al. (2020) also showed an increase in knowledge about maintaining personal hygiene through washing hands in daily life to prevent the transmission of COVID-19 [15].

There are two main influencing factors such as behavioral factors and non-behavioral factors. According to B. Bloom, there are three behavior domains: knowledge, attitude, and action. Meanwhile, health behavior, according to L. Green, is influenced by three factors, namely predisposing factors, enabling factors, and driving factors [5]. From predisposing factors, we could see that people have sociodemographic factors that are different from one another, such as differences in age, gender, education, occupation, educational or occupational background, and area of origin. The description of these sociodemographic characteristics can influence people's behavior and outcomes in the form of public health [16]. Studies by Purnamasari et al. (2020) and Syakurah et al. (2020) state that there is a significant relationship between knowledge and community behavior towards COVID-19 [17] [18]. Public knowledge also has a close relationship with compliance with masks [19]. Good behavior can fortify us from the transmission of COVID-19 [20]. Therefore, education is necessary to increase public knowledge and correct public misperceptions regarding information about COVID-19 and how to prevent it. Proper knowledge can produce results in implementing behavior to prevent transmission of COVID-19 and clean and healthy living behavior.

A study by Chawla et al. (2019) found that effective health education improved knowledge, attitude, and practices, particularly with regard to lifestyle modifications and dietary management in patient with type 2 Diabetes Mellitus, thus slowing the progression of disease and preventing its complications [21]. Health education is an essential method toto aware people about the importance of healthy behaviour in preventing COVID-19 infection. COVID-19 poses great financial burden and calls for urgent participation, not just clinicians and health care workers, but everyone to inform and motivate each other about healthy lifestyle practices vital for achieving glycemic control. A study by Ricky et al. (2021) depicted the interest of the youth generation to withstand COVID-19 and hepatitis B by joining a health ambassador program. It showed that the majority motivation to join the ambassador program was they want to help to suppress COVID-19 and hepatitis B burden through health promotion along with gaining new experience. The study found that there was a significant correlation between the participants' commitments to the degree of knowledge reflecting 
that commitment is an essential factor to increase the knowledge of youths regarding COVID-19. Knowing the motivation, commitment, and knowledge of the young generation might be an important step to gain the support of youths in health promotion programs [22].

Health education tries to increase the health status of all levels of society unfailingly, by providing knowledge through the learning activities provided. The importance of providing health education must also be accompanied by paying attention to various factors that support the acceptance of information conveyed more quickly to listeners, one of which is by using a simple language, which can be understood by health education participants, the information or topics given are not complicated and also related to health in the community. The use of various techniques or methods is also very necessary in delivering messages to health education participants, such as teaching aids [23]. Providing health education counseling for children can aim to increase knowledge, create healthy attitudes and behavior, and can form healthy living habits. The effect of providing health education can be proven from the results of Kusbiantoro's (2015) research that there is an effect of health education on how to wash hands before and after health education. In addition, in Fauzie and Herawati's (2014) research which examined the effect of counseling on increasing motivation and action in washing hands, it was found that the most appropriate method used to improve action was by way of lectures accompanied by the practice during counseling and good methods were used. In terms of improvement actions, i.e. through lectures played with accompanying videos [24].

\section{Conclusion}

Providing education using PowerPoint media, educational videos, and direct practice of proper handwashing can increase knowledge about COVID-19 and its prevention. Continuous education about COVID-19 and how to prevent its transmission is necessary to increase public knowledge and improve public perception due to the influence of false information circulating by hoax busters. People's behavior towards preventing COVID-19 will develop along with increasing knowledge about COVID-19 and how to prevent it.

\section{Acknowledgements}

The authors would like to thank the Al-Jihad Islamic Boarding School Surabaya Indonesia for supporting this research.

\section{References}

[1] Kemenkes RI, "Pedoman Pencegahan dan Pengendalian CORONAVIRUS DISEASE (COVID-19)", Revisi ke-5 [Internet], 2020 [Cited July 21, 2021], Available from: https://covid19.go.id/p/protokol/pedoman-pencegahan-dan-pengendaliancoronavirus-disease-covid-19-revisi-ke-5.

[2] Satuan Tugas Penanganan COVID-19 (Satgas COVID-19), "Situasi Virus COVID-19 di Indonesia" [Internet], 2021 [Cited July 21, 2021], Available from: https://covid19.go.id/.

[3] Center of Disease Prevention and Control, "COVID-19 in Indonesia" [Internet], 2021 [Cited July 23, 2021], Available from: https://wwwnc.cdc.gov/travel/notices/covid-4/coronavirus-indonesia.

J. D. T. Donsu, "Psikologi Keperawatan", Yogyakarta: Pustaka Baru Press. Cetakan I, 2019.

S. Notoatmodjo, “ Ilmu Perilaku Kesehatan. 2nd ed”,Jakarta: Rineka Cipta, 2014.

C. Silalahi, B. Lampus, R. Akili, U. Sam, R. Manado, "Hubungan Antara Pengetahuan Dan Sikap Perawat Tentang HIV/AIDS Dengan Tindakan Perawat Terhadap Penderita HIV/AIDS Di Rumah Sakit Pancaran Kasih Manado", Media Kesehatan FKM Unsrat, vol. 46, pp. 1-5, Available from: https://fkm.unsrat.ac.id/wp-content/uploads/2013/08/JURNALCHRISTINE-SILALAHI-09.pdf.

[7] Ahmadi, "Kesehatan Masyarakat, Teori Dan Aplikasi”, Jakarta: Raja Grafindo, 2013, Available from: http://r2kn.litbang.kemkes.go.id/handle/123456789/74403. 
[8] D. Purbayanti, R. Ardina, \& H. Suryadini, "Peningkatan Pengetahuan tentang Pencegahan Infeksi dan Penyebaran Penularan COVID-19 di Panti Asuhan/LKSA Darul Tazkiyah Kota Palangka Raya”, PengabdianMu: Jurnal Ilmiah Pengabdian Kepada Masyarakat, vol. 6, no. 3, pp. 222-229, 2021, doi: 10.33084/pengabdianmu.v6i3.1917.

[9] A. S. Rahmadeni, N. Hayat, R. Novia, D. Siska, \& D. Yunaspi, "Penyuluhan Perilaku Hidup Bersih Dan Sehat Dan Pembagian Sembako Pada Anak Di Panti Asuhan Mahabbatul Haq Tanjung Uma Batam”, Jurnal Abdimas Saintika, vol. 1, no. 1, pp. 141-144, 2019, doi: 10.30633/jas.v1i1.485.

[10] A. Y. Zukmadini, B. Karyadi, \& K. Kasrina, "Edukasi Perilaku Hidup Bersih Dan Sehat (PHBS) Dalam Pencegahan Covid-19 Kepada Anak-Anak Di Panti Asuhan", Jurnal Pengabdian Magister Pendidikan IPA, vol. 3, no. 1, 2020, doi: 10.29303/jpmpi.v3i1.440.

[11] F. Erlin, I. D. Putra, \& D. Hendra, "Peningkatan Pengetahuan Siswa Dalam Pencegahan Penularan COVID-19”, JMM (Jurnal Masyarakat Mandiri), vol. 4, no. 4, pp. 663-669, 2020, doi: 10.31764/jmm.v4i4.2652.

[12] T. Sulistyaningtyas, J. Jaelani, \& Y. Suryani, "Power Of Knowledge And Community Social Class Above Covid-19 Pandemic Information On Social Media", Jurnal Komunikasi Ikatan Sarjana Komunikasi Indonesia, vol. 5, no. 1, pp. 52-62, 2020, doi: 10.25008/jkiski.v5i1.372.

[13] R. Olum, G. Chekwech, G. Wekha, D. R. Nassozi, \& F. Bongomin, "Coronavirus Disease-2019: Knowledge, Attitude, And Practices Of Health Care Workers At Makerere University Teaching Hospitals, Uganda”, Frontiers In Public Health, vol. 8, pp. 181, 2020, doi: 10.3389/fpubh.2020.00181.

[14] B. L. Zhong, W. Luo, H. M. Li, Q. Q. Zhang, X. G. Liu, W. T. Li, "Knowledge, Attitudes, And Practices Towards COVID-19 Among Chinese Residents During The Rapid Rise Period Of The Covid-19 Outbreak: A Quick Online Cross-Sectional Survey", Int J Biol Sci, vol. 16, no. 10, pp. 1745-52, 2020, doi: 10.7150/ijbs.45221.

[15] D. K. Wardhani, M. R. Susilorini, L. J. Angghita, \& A. Ismail, "Edukasi Pencegahan Penularan COVID-19 Pada Anak Usia Dini Melalui Media Pembelajaran Audio Visual”, Jurnal Abdidas, vol. 1, no. 3, pp. 131-136, 2020, doi: 10.31004/abdidas.v1i3.33.

[16] A. Widayati, S. Suryawati, C. de Crespigny, \& J. E. Hiller, "Knowledge And Beliefs About Antibiotics Among People In Yogyakarta City Indonesia: A Cross-Sectional Population-based Survey. Antimicrobial Resistance And Infection Control" Antimicrobial Resistance and Infection Control, vol. 1, no. 1, pp 38, 2012, doi: 10.1186/2047-2994-1-38.

[17] I. Purnamasari, \& A. E. Raharyani, "Tingkat Pengetahuan Dan Perilaku Masyarakat Kabupaten Wonosobo Tentang COVID-19", Jurnal Ilmiah Kesehatan, vol. 10, no. 1, pp. 33-42, 2020, Available from: https://ojs.unsiq.ac.id/index.php/jik/article/view/1311 .

[18] R. A. Syakurah, \& J. Moudy, "Pengetahuan Terkait Usaha Pencegahan Coronavirus Disease (Covid-19) Di Indonesia", HIGEIA (Journal of Public Health Research and Development), vol. 4, no. 3, pp. 333-346, 2020, doi: 10.15294/higeia.v4i3.37844.

[19] D. P. Sari, \& N. Sholihah"Atiqoh, "Hubungan Antara Pengetahuan Masyarakat Dengan Kepatuhan Penggunaan Masker Sebagai Upaya Pencegahan Penyakit Covid-19 Di Ngronggah", Infokes: Jurnal Ilmiah Rekam Medis Dan Informatika Kesehatan, vol. 10, no. 1, pp. 52-55, 2020, doi: 10.47701/infokes.v10i1.850.

[20] A. O. A. W Lestari, "Hubungan Pengetahuan Dan Sikap Terhadap Perilaku Cuci Tangan Pada Masyarakat Kelurahan Pegirian", Jurnal Promkes: The Indonesian Journal of Health Promotion and Health Education, vol. 7, no. 1, pp. 1-11, 2019, doi: 10.20473/jpk.V7.I1.2019.1-11.

[21] S. P. S. Chawla, et al, "Impact Of Health Education On Knowledge, Attitude, Practices And Glycemic Control In Type 2 Diabetes Mellitus", Journal of Family Medicine and Primary Care, vol. 8, no. 1, pp. 261, 2019, doi : $10.4103 /$ jfmpc.jfmpc_228_18.

[22] R. I. Alfaray, et al, "Covid-19 And Hepatitis B Ambassador Of Surabaya, Indonesia: Motivation, Commitment, And Knowledge Of Youth Generation Towards Health Programs In The Pandemic Era”, Gaceta Medica de Caracas, S390-S402, 2021, doi : $10.47307 /$ GMC.2021.129.s2.17.

[23] V. Simanjuntak, "Pengaruh Pendidikan Kesehatan terhadap Pengetahuan, Sikap dan Tindakan Keluarga dalam Deteksi Dini Kesehatan Jiwa Anak Usia Sekolah di Kelurahan Sunggal Kota Medan” [Internet], 2019 [Cited by January 13, 2022], Available from : https://repositori.usu.ac.id/bitstream/handle/123456789/24197/151101121.pdf?sequence=1\&isAllowed=y.

[24] G. R. Tanari,et al "Dampak Edukasi Menggunakan Media Audio Visual Terhadap Pengetahuan Dan Keterampilan Mencuci Tangan Anak", Jurnal Keperawatan Florence Nightingale, vol. 3, no. 1, pp. 1-6, 2020, doi : 10.52774/jkfn.v3i1.44. 